\title{
EKONOMIKA
}

\section{ALTERNATYVAUS INVESTAVIMO FONDŲ REGULIAVIMO LIETUVOJE RAIDA IR TOBULINIMO GALIMYBĖS}

Prof. Dr. Biruté GalinienĖ

Vilniaus universiteto Ekonomikos fakultetas

Vilnius University Faculty of Economics

Sauletekio al. 9, LT-10222 Vilnius

El.paštas birute.galiniene@ef.vu.lt

Dr. GyTis JARAšIUS

Vilniaus universiteto Ekonomikos fakultetas

Vilnius University Faculty of Economics

Sauletekio al. 9, LT-10222 Vilnius

El.paštasgytisj@gmail.com

\section{Santrauka}

Alternatyvaus investavimo fondai Lietuvoje ịteisinti $2008 \mathrm{~m}$. pradžioje ir jau spejo ịsitvirtinti Lietuvos investiciniu fondu rinkoje. Todèl tokiu fondu teisinis reguliavimas ir priežiüra tampa dar svarbesne, nes jie yra potencialiai pavojingesni finansu sistemai nei iprastiniai investiciniai fondai. Nors nuo šiu fondu įteisinimo įvyko nemažai investiciniu fondu teisinio reguliavimo pokyčių, atlikta analize atskleidè, kad srityse, kuriose yra reikšminga galimybe atsirasti sisteminei rizikai, alternatyvaus investavimo fondu reguliavimas galètų büti griežtesnis ir priežiūra intensyvesnè. 
Reikšminiai žodžiai: alternatyvaus investavimo fondai; kolektyvinio investavimo subjektai; finansinis svertas; alternatyvaus investavimo fondų teisinis reguliavimas; profesionalusis investuotojas; informuotasis investuotojas.

\section{Ivadas}

Rinkos egzistavimą ir efektyvų jos funkcionavimą nemaža dalimi lemia teisinè aplinka, jos plètra ir patrauklumas regioniniu mastu. Lietuvos investicinių fondų rinka nuolat plečiasi ir sparčiai tobulejja, tai rodo ir pradejję veikti alternatyvaus investavimo fondai (toliau - AIF). Šių fondų atsiradimas lèmè nemažus pokyčius teisès aktuose. Nors AIF, palyginti su ịprastiniais investiciniais fondais, suteikia papildomų privalumų, tačiau jie gali kelti ir papildomų problemų, jei nebus tinkamai prižiūrimi. Todèl šio straipsnio tikslas yra išanalizuoti AIF veiklą Lietuvoje įvertinant teisinị šių fondų reguliavimą ir aptariant jų reguliavimo trūkumus ir tobulintinas sritis.

Siekiant iškelto tikslo atlikta teisès aktų ir literatūros analizè, pasitelkti lyginamosios statistikos ir ekspertinio vertinimo metodai. Verta paminèti, kad tarptautiniu mastu AIF veikla nèra plačiai nagrinejjama, ypač analizuojant bendrąją AIF rinką, o su šių fondų reguliavimu susiję klausimai aptariami dar rečiau. Lietuvoje ši sritis tyrinèta mažiau, tai susiję su santykinai trumpa jų veikla mūsų valstybeje. Atsižvelgiant ị sparčią AIF plètrą, jų potencialiai keliamas grèsmes ir dažną teisinio reguliavimo kaitą Lietuvoje, straipsnyje nagrinejjama tema yra itin aktuali ir jai turi būti skiriamas deramas dèmesys. 


\section{AIF atsiradimas ir tolesnè raida Lietuvoje}

Pirmųjų investicinių fondų atitikmenys pasaulyje pradejo formuotis dar XVIII a., tačiau Lietuvoje pirmasis investicinis fondas ìsteigtas tik $2001 \mathrm{~m}$. pradžioje. $2003 \mathrm{~m}$. prièmus Lietuvos Respublikos kolektyvinio investavimo subjektų ir Lietuvos Respublikos kontroliuojančiųjų investicinių bendrovių isstatymus, investicinių fondų plètra labai paspartejo. Tai puikiai iliustruoja istoriniai duomenys - nuo 1995 m. iki 2003 m., kol galiojo Lietuvos Respublikos investicinių bendrovių îstatymas, buvo įsteigti 2 investiciniai fondai, o vien tik per $2004 \mathrm{~m}$. - devyni nauji investiciniai fondai ${ }^{1}$ (čia ir toliau straipsnyje duomenys nagrinejjami neįtraukiant pensijų fondų skaičiaus ir jų valdomo turto duomenų). Galima manyti, kad tokị spartų augimą lėmè makroekonominès priežastys ir pribrendusi tokių paslaugų paklausa, tačiau fondų skaičiaus augimą neabejotinai nulėmé priimti teisès aktai. Tai vaizdžiai liudija apie teisinio reguliavimo ir tinkamų veiklos normatyvų bei taisyklių nustatymo svarbą, nes tik sudarius tinkamas ir pagrịstas sąlygas veiklai galima tikètis efektyvios ir rinkos lūkesčius atitinkančios plètros.

2008 m. kovo mèn. pradžioje i̇sigaliojus naujajai Kolektyvinio investavimo subjektų ístatymo (toliau - KISI) redakcijai buvo sudarytos teisinès sąlygos Lietuvoje steigti ir specialiuosius kolektyvinio investavimo subjektus, vienos iš šių subjektų rūšių buvo privataus kapitalo, nekilnojamojo turto ir alternatyvaus kolektyvinio investavimo fondai. Nors ir egzistuoja tam tikrų skirtumų, apibrèžiant alternatyvias investicijas ir su jomis susijusius fondus, tačiau pagrịstai galima teigti, jog nagrinejjamu metu AIF derètų priskirti trijų rūšių fondus: rizikos draudimo fondus (toliau - RDF) (angl. hedge funds), privataus kapitalo fondus (toliau - PKF) ir nekilnojamojo turto fon-

Metinės ataskaitos ir finansinių priemonių rinkos apžvalgos (2015). Lietuvos Respublikos vertybinių popierių komisija. Prieiga per internetą: http:/www.lb.lt/ vertybiniu_popieriu_komisijos_apzvalgos. 
dus (toliau - NTF). Minètą AIF rūšių skirstymą grafiškai vaizduoja 1 paveikslèlis. Toki požiūrị i AIF klasifikaciją paremia ir KISI aprašomos specialiųjų KIS rūšys - šiame įstatyme reglamentuojamos tik šių trijų rūšių AIF.

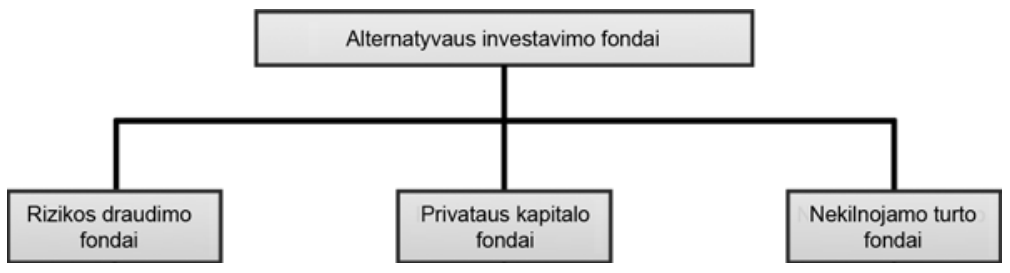

1 pav. AIF rūšys

Šaltinis: Jarašius, G., $2014^{2}$

Vis dèlto nagrinèjant Lietuvoje vyraujantị požiūrị, galima pastebèti, kad kai kuriais atvejais AIF tiek mokslineje literatūroje, tiek viešajame gyvenime yra suvokiami ir vertinami per siaurai, țtraukiant ne visas AIF rūšis, kurios turètų priklausyti šiai kategorijai. Prie to prisideda ne tik atskiruose žemynuose taikomos skirtingos klasifikacijos, bet ir tam tikra sąvokų painiava, atsiradusi užsienio terminus pritaikant vietinei rinkai. Tai puikiai iliustruoja KISI vartojama terminologija. Šiame istatyme vartojama sąvoka alternatyvaus kolektyvinio investavimo subjektai, kuri apibūdina tik vieną iš specialiųjų KIS rūšių - RDF. Tačiau dèl vartojamos formuluotès gali kilti neaiškumų ir abejonių, nes tokia sąvoka populiariai gali būti suprantama kaip AIF apskritai, nors AIF apima keleto rūšių fondus, ne vien tik RDF. Minèti neatitikimai iškyla dèl Lietuvoje dar besiformuojančios AIF terminijos ir dèl vis dar pasitaikančių terminų vertimo iš užsienio kalbos skirtumų. Derètų paminèti, kad iškelta problema yra labiau teorinio pobūdžio, nes specializuotoje ir techni-

2 Jarašius, G. Alternatyvaus investavimo fondu ịtaka Lietuvos ekonomikai: daktaro disertacija. Vilniaus universitetas. Vilnius, 2014. 265 p. 
nejje literatūroje šios sąvokos yra tinkamai atskiriamos ir vartojamos. Vis dèlto toks terminų neatitikimas ir vertimų interpretacijos neprisideda prie aiškios terminijos kūrimo, ypač atsižvelgiant i tai, kad šie fondai Lietuvoje vis dar yra investicinè naujové, žinoma ir gerai suvokiama tik siaurame specialistų rate.

Nagrinejjant globaliu mastu, alternatyvios investicijos ir susidomejjimas AIF laikui bejgant dideja, o tokios investicijos igyja ir vis didesnę svarbą bendrame investicijų kontekste. Kaip rodo Finansų planavimo asociacijos (angl. Financial Planing Association) atlikta apklausa, matoma tendencija, jog alternatyvios investicijos pasauliniu mastu iggauna vis didesnę dalị tarp bendrų investicijų ${ }^{3}$. Tai gali būti aiškinama viena iš pagrindinių alternatyvių investicijų ypatybių - menkos koreliacijos su kitais, tpprastiniais, investavimo instrumentais (akcijomis, obligacijomis), taip pat prie šių fondų populiarejjimo prisideda ir jų uždarumas, didesnè veiksmų ir investicinių instrumentų pasirinkimo laisvė bei galimybė gauti nuo rinkos svyravimų mažiau priklausomą rezultatą.

Kaip matyti iš 2 paveikslèlio duomenų, Lietuvoje registruotų AIF turto dalis visų šalyje registruotų KIS turte 2014 m. pabaigoje išaugo net iki 44,3 proc. (tai yra pati didžiausia dalis nuo AIF veiklos Lietuvoje pradžios). Santykinè AIF valdomo turto dalis nuolat sparčiai augo, kartu didejo ir AIF valdomo turto apimtys. Lietuva taip pat neatsilieka nuo pasaulinių tendencijų ir mūsų šalyje AIF tampa vis populiaresni. Staigus AIF valdomo turto ir dalies KIS valdomame turte augimas, viršijantis kitų KIS rinkos augimą, rodo, kad Lietuvoje jie buvo ịteisinti laiku, ypač turint omenyje, jog tai padaryta 2008 m. viduryje - per patị pasaulinès finansų ir ekonomikos krizės, kuri smarkiai paveikė ir Lietuvos kapitalo rinką, įkarštį.

3 Schulaka, C. Special report: 2011. Alternative investments. Journal of financial planing. 3 p. Prieiga per internetą: http://www.fpanet.org/docs/assets/4A726F421D09-67A1-7AE0CA9E420DAD2F/SS_Schulaka.pdf. 


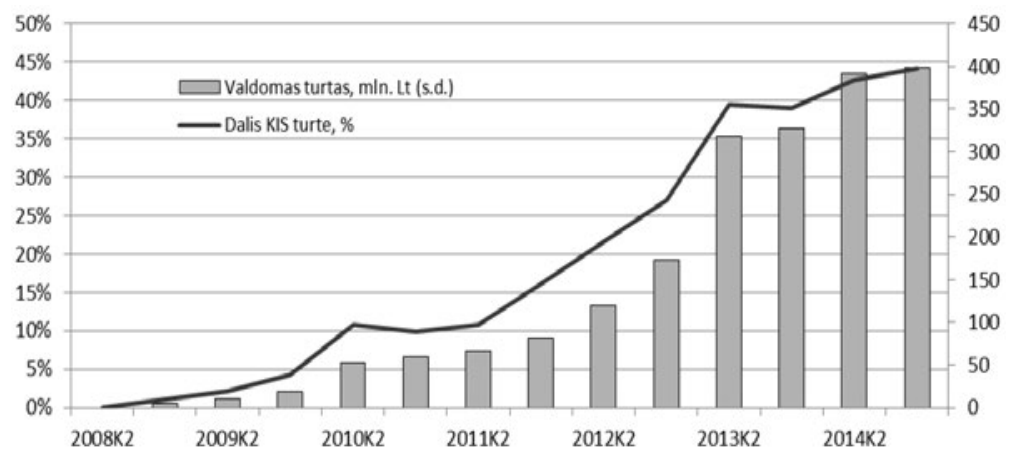

2 pav. AIF dalis Lietuvos KIS rinkoje 2008-2014 metais

Šaltinis: sudaryta autorių, remiantis Lietuvos ..., $2015^{4}$

Lietuvoje veikiančių AIF plètros tendencijas Baltijos šalių kontekste atskleidžia 3 paveikslèlyje pateikti Estijoje ir Lietuvoje registruotų AIF valdomo turto duomenys, kurie palyginti su kitais šalyje veikiančiais KIS subjektais. Analizuojant pateiktus duomenis matoma aiški tendencija - Estijoje AIF valdo žymiai daugiau turto, tačiau šių fondų valdomo turto santykinė dalis yra panaši, nors ir gerokai stabilesnè, nei analogiškas rodiklis Lietuvoje. $2014 \mathrm{~m}$. viduryje Estijoje registruotų AIF valdomo turto santykis su kitų KIS turtu siekė 26,9 proc., o Lietuvoje šis rodiklis sudare 42,7 proc.

4 Lietuvos bankas (2015). Kolektyvinio investavimo subjektų rinkos apžvalgos. Prieiga per internetą: http://www.lb.lt/apzvalgos_prognozes. 


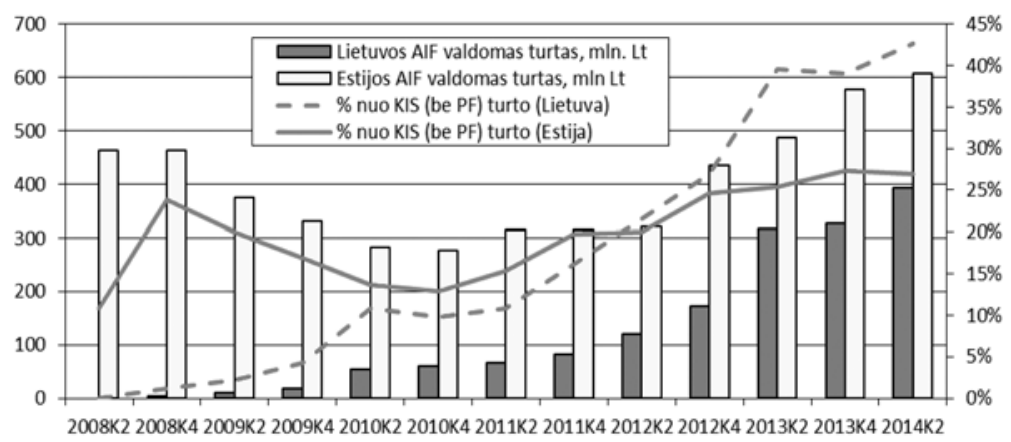

\section{3 pav. Lietuvos ir Estijos AIF palyginimas 2008-2014 m.}

Šaltinis: sudaryta autorių, remiantis Lietuvos..., 2015 , Estonian..., $2015^{6}$

Matyti, kad tik paskutiniais nagrinejjamais laikotarpiais Lietuvoje registruotų AIF valdomo turto santykis pradejo viršyti Estijos AIF valdomo turto santykį. Taigi nors Lietuvoje registruoti AIF užima didesnę rinkos dalị, tačiau absoliutus valdomo turto dydis dar nesiekia Estijoje fiksuojamo dydžio. Atsižvelgiant ir ị geografiškai mažesnę Estijos rinką, galima spręsti, kad Lietuvos AIF plètros potencialas yra optimistinis ir ateityje mūsų valstybeje registruoti AIF sudarys vis didesnę dalị KIS rinkoje, jeigu tik jų veiklai bus sudarytos tinkamos sąlygos. Augantis populiarumas kartu kelia ir grèsmių, nes AIF labiau nei ịprastiniai fondai gali paveikti šalies kapitalo rinką ir ekonomiką. Todèl AIF raidai ir teisiniam reglamentavimui turi būti skiriamas deramas dèmesys.

Viena iš investicijų ir investicinių fondų populiarinimo Lietuvoje priemonių buvo ir Informuotiesiems investuotojams skirtų kolektyvinio investavimo subjektų ịstatymo (toliau - IIKISI) prièmimas (AIF taikomas reguliavimas išsamiau analizuojamas toliau tekste). $2013 \mathrm{~m}$.

5 Ten pat.

6 Estonian financial market overwievs (2015). Estijos finansinės priežiūros institucija.

Prieiga per internetą: http://www.fi.ee/index.php?id=12737. 
viduryje ịsigaliojusiu IIKISI buvo siekiama supaprastinti investicinių fondų, ypač AIF, reguliavimą ir išplèsti investuotojų skaičių. Kaip matyti iš 4 paveikslèlyje pateiktų duomenų, preliminariai galima teigti, kad IIKISI savo tikslus pasiekè, nes AIF, veikiančių pagal IIKISI, skaičius augo itin sparčiai. Vis dèlto bendras AIF skaičius didejo neryškiai, nes dalis AIF, veikusių pagal KISI, baigè savo veiklą arba prisitaikè prie IIKISI reikalavimų ir dabar yra reglamentuojami šio ịstatymo.

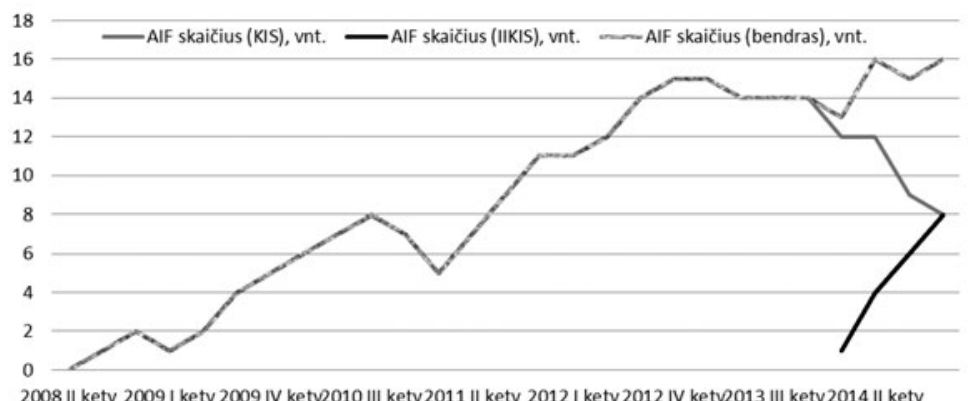

2008 II ketv 2009 I ketv 2009 IV ketv2010 III ketv2011 II ketv 2012 I ketv 2012 IV ketv2013 III ketv2014 II ketv

4 pav. AIF skaičiaus Lietuvoje kitimas 2008-2014 m.

Šaltinis: sudaryta autorių, remiantis Lietuvos..., $2015^{7}$

Dèl išdėstytų faktų ir nuolat didejjančios AIF svarbos ir populiarumo Lietuvoje kyla poreikis išsamiai analizuoti šių fondų veiklą ir jų ịtaką Lietuvos kapitalo rinkai bei ekonomikai apskritai. Kartu dèmesys turi būti nukreiptas ir į teisinị šių fondų reguliavimą, nes, kaip rodo istoriniai duomenys, teisès aktų reguliavimas yra itin reikšmingas AIF kūrimuisi ir jų veiklos perspektyvoms, teisinès normos netiesiogiai lemia ir galimą šių fondų itaką ekonomikai. Situaciją komplikuoja ir prasidèjęs tam tikras pereinamasis laikotarpis, kuriuo anksčiau įsisteigę AIF gali veikti pagal KISI, taip pat steigiasi ir IIKISI reglamentuojami fondai. Atsižvelgiant $\mathfrak{i}$

7 Lietuvos bankas (2015). Kolektyvinio investavimo subjektų rinkos apžvalgos.

Prieiga per internetą: http://www.lb.lt/apzvalgos_prognozes. 
AIF, veikiančių pagal KISI ar pagal IIKISI, skaičiaus struktūrą, kitusią po IIKISI įteisinimo, galima teigti, jog nagrinèjamu metu aktualūs išlieka abu teisès aktai. Tai rodo ir IIKISI svarbą bei indèli gerinant investicines sąlygas fondams ir investuotojams, tačiau pernelyg didelè veiksmų laisvẻ gali kelti ir papildomų rizikų, todèl toliau analizuojama teisiné AIF aplinka Lietuvoje, jos plètra ir galimi trūkumai.

\section{AIF teisinis reguliavimas Lietuvoje}

Nuo 2008 m. pradžios, Lietuvoje ịteisinus AIF, ịvyko nemažai teisinio reguliavimo pokyčių. Priimant su AIF susijusius teisès aktus, Lietuva jau buvo Europos Sąjungos narè, todèl buvo perimama ES patirtis ir ị nacionalinę teisę perkeliamos Europos Parlamento ir Tarybos direktyvos. Vis dèlto per santykinai trumpą laiką buvo atlikta nemažai priimtų teisès aktų pakeitimų. Atliktų veiksmų visumą gerai atskleidžia 5 paveikslèlyje pateikta schema.

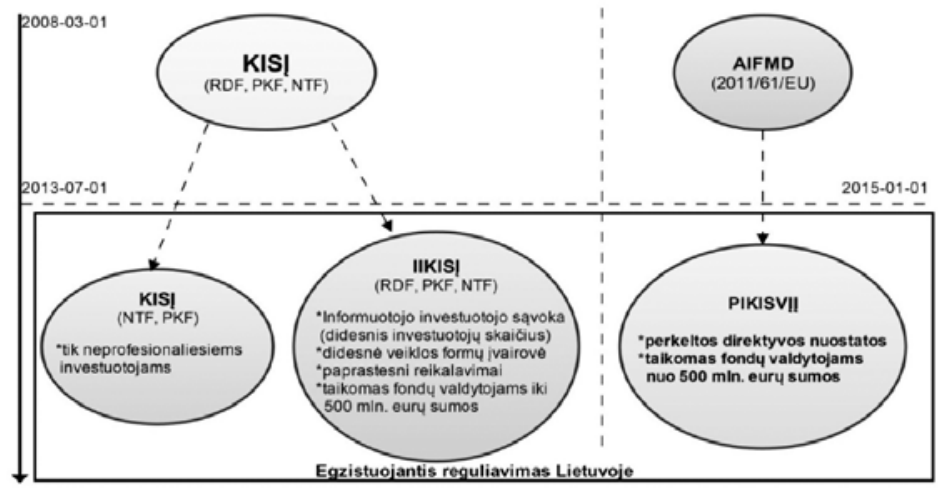

5 pav. Lietuvos teisès aktų, reguliuojančių AIF, raida Šaltinis: sudaryta autorių

Ilgą laiką pagrindinis ịstatymas, reguliuojantis Lietuvoje veikiančius 
investicinius fondus, buvo Kolektyvinio investavimo subjektų ịstatymas. 2003 m. priimtame KISI apie AIF nebuvo užsiminta, reglamentuojami tik ịprasti investiciniai fondai. Kaip nurodo G. Jarašius, tikètina, kad tuomet Lietuvos rinka dar buvo nepasiruošusi didelei ir sudètingai investicinių priemonių ịvairovei, todèl AIF šiame įstatyme dar nebuvo įteisinti ${ }^{8}$. 2007 m. lapkričio mèn. buvo priimta nauja KISI redakcija, kuri sudare sąlygas steigtis specialiesiems KIS, tokiems kaip PKF, NTF ir RDF (jie galejo būti ir uždaro tipo). Itstatymas įsigaliojo nuo $2008 \mathrm{~m}$. kovo $1 \mathrm{~d}$., tai yra oficiali data, kada Lietuvoje buvo itteisinta AIF registracija.

Nuo $2013 \mathrm{~m}$. vidurio atsirado du teisès aktai, reguliuojantys AIF. Naujojo teisès akto (IIKISI) prièmimas nèra susijęs su ES direktyvos perkèlimu, priimant ši ịstatymą buvo siekiama sukurti lankstesnị KIS teisinị reguliavimą ir paskatinti KIS plètrą Lietuvoje ${ }^{9}$. Šis įstatymas buvo kurtas vadovaujantis pasauline praktika ir perimant galiojantį fondų reguliavimą iš kitų Europos valstybių (konkrečiai - Liuksemburgo atvejis), turinčių gerai išplètotą fondų rinką. Prièmus Profesionaliesiems investuotojams skirtų kolektyvinio investavimo subjektų valdymo įmonių ịstatymą (toliau - PIKISVIt), buvo užbaigti Lietuvos teisinès sistemos KIS reguliavimo procesai, ir nuo $2015 \mathrm{~m}$. pradžios Lietuvoje lygiagrečiai veikia 3 teisès aktai, reguliuojantys AIF. Pagal KISI besisteigiantys AIF galès būti skirti tik neprofesionaliesiems investuotojams ir tik teoriškai galètų būti vadinami AIF, nes neprofesionaliesiems investuotojams skirtiems KIS yra taikomi didesni apribojimai tiek pagal investavimo priemonių pasirinkimą ir naudojimą, tiek pagal investuotojų apsaugą ir atskaitomybę. Taip pat pagal naujausią KISI redakciją reguliuojami tik dviejų rūšių specialieji KIS (NTF ir PKF), o RDF i ši îstatymą nebepatenka. Todèl laukiama, kad didžioji dalis naujai steigiamų AIF veiks pagal IIKISI, o

8 Jarašius, G. Alternatyvaus investavimo fondu įtaka Lietuvos ekonomikai: daktaro disertacija. Vilniaus universitetas. Vilnius, 2014. 265 p.

9 Numatomi pasikeitimai fondų veiklos reguliavime Lietuvoje ir Europos Sajungoje (2012). Lietuvos Respublikos finansų ministerija. Prieiga per internetą: http://www. finmin.lt/finmin.lt/failai/Finansu_rinkos/fm_pristatymas_fondai_LT_EU.pdf. 
tais atvejais, jei fondo valdymo įmonès valdomas turtas viršytų $500 \mathrm{mln}$. eurų (100 mln. eurų, jei naudojamas svertas), jam turètų būti taikomos PIKISVIt nuostatos. Ši reguliavimo schema grafiškai pateikta 5 paveikslèlio apatineje dalyje nubraižytame stačiakampyje.

Grafiškai 5 paveikslèlyje pateiktų teisès aktų raida detaliau išskaidoma 1 lentelèje. Lentelès duomenys patvirtina išsakytą mintị, jog buvo atlikta nemažai teisès aktų pakeitimų, taip pat keletą kartų kurtos naujos KISI redakcijos. Galima manyti, kad nè vienai suinteresuotai pusei nèra naudinga tokia teisès aktų kaita, nes tai gali mažinti ir investuotojų, ir potencialių fondų valdytojų pasitikejjimą ịstatymus leidžiančia valdžia ir kartu stabdyti fondų plètrą. Vis dèlto KISI reglamentuoja ne vien tik AIF, analogiškai ir ne visi įstatymo pakeitimai buvo susiję tiesiogiai su AIF veikla, taip pat dalis pakeitimų buvo itin smulkūs ir nereikšmingi. Atsižvelgiant ị tai verta nustatyti, ar santykinai dažnas i̊statymo kaitaliojimas, naujų struktūrų kūrimas ir juridinès veiklos formų plètimas galèjo turèti įtakos AIF veiklai Lietuvoje.

\section{1 lentelè. Teisès aktų, reguliuojančių AIF, kaita}

\begin{tabular}{|c|c|c|c|}
\hline $\begin{array}{l}\text { Eil. } \\
\text { nr. }\end{array}$ & $\begin{array}{l}\text { Istatymo data } \\
\text { ir numeris }\end{array}$ & Pakeitimo turinys & Pastabos \\
\hline 1 & $\begin{array}{l}2007 \text { m. spalio } \\
25 \text { d. Nr. } \\
\text { X-1303 }\end{array}$ & Iteisinti alternatyvaus investavimo fondai. & $\begin{array}{l}\text { Issigaliojo nuo } \\
\text { 2008-03-01. }\end{array}$ \\
\hline 2 & $\begin{array}{l}2008 \text { m. bir- } \\
\text { želio } 19 \text { d. Nr. } \\
\text { X-1630 }\end{array}$ & $\begin{array}{l}\text { Papildyti sąvoku apibrèžimai, pakeistas } \\
\text { straipsnis apie indekso investicinius fon- } \\
\text { dus. }\end{array}$ & $\begin{array}{l}\text { AIF reguliavi- } \\
\text { mui pakeitimai } \\
\text { reikšmingos } \\
\text { itakos neturi. }\end{array}$ \\
\hline 3 & $\begin{array}{l}2009 \text { m. kovo } \\
19 \text { d. Nr. XI- } \\
204\end{array}$ & $\begin{array}{l}\text { Pakeisti apibrèžimai, straipsnio apie valdy- } \\
\text { mo įmonès akcijų įsigijimą ir perleidimą } \\
\text { nuostatos, taip pat NTF atžvilgiu įtrauktas } \\
\text { dar vienas KISI punktas (draudimas igy- } \\
\text { ti esminị poveikị emitentui), kuriuo NTF } \\
\text { neprivalo vadovautis. }\end{array}$ & $\begin{array}{l}\text { Isigaliojo 2009- } \\
\text { 04-04. NTF } \\
\text { galès turèti } \\
\text { didesnę ittaką } \\
\text { emitentui. }\end{array}$ \\
\hline 4 & $\begin{array}{l}2010 \text { m. bir- } \\
\text { želio } 3 \text { d. Nr. } \\
\text { XI- } 873\end{array}$ & $\begin{array}{l}\text { Pakeisti apibrèžimai, kiti straipsniai, nesu- } \\
\text { siję su AIF. Papildyta NTF veiklą reguliuo- } \\
\text { janti KISI } 75 \text { straipsnio } 2 \text { dalis. }\end{array}$ & $\begin{array}{l}\text { NTF investicijų } \\
\text { diversifikavimo } \\
\text { taisyklès tapo } \\
\text { aiškesnès. }\end{array}$ \\
\hline
\end{tabular}




\begin{tabular}{|c|c|c|c|}
\hline 5 & $\begin{array}{l}2011 \mathrm{~m} . \\
\text { lapkričio } 17 \mathrm{~d} . \\
\text { Nr. XI-1674 }\end{array}$ & $\begin{array}{l}\text { Papildyta su AIF nesusijusiais straipsniais, } \\
\text { reglamentuojančiais suderintuosius KIS. }\end{array}$ & $\begin{array}{l}\text { Nauja istaty- } \\
\text { mo redakcija. } \\
\text { Isigaliojo nuo } \\
\text { 2012-01-01. }\end{array}$ \\
\hline 6 & $\begin{array}{l}2012 \text { m. bir- } \\
\text { želio } 26 \text { d. Nr. } \\
\text { XI-2122 }\end{array}$ & $\begin{array}{l}\text { Apibrežtas minimalus KIS grynuju ak- } \\
\text { tyvų dydis; išplèsti NTF diversifikavimo } \\
\text { reikalavimai; pakeisti maksimalūs sverto } \\
\text { ir skolinimo dydžiai; papildyta kitais tie- } \\
\text { siogiai su AIF nesusijusiais straipsniais, } \\
\text { reglamentuojančiais suderintuosius KIS. }\end{array}$ & $\begin{array}{l}\text { Nauja istaty- } \\
\text { mo redakcija. } \\
\text { Isigaliojo nuo } \\
2012-07-01\end{array}$ \\
\hline 7 & $\begin{array}{l}2013 \text { m. bir- } \\
\text { želio } 18 \text { d. Nr. } \\
\text { XII-375 }\end{array}$ & $\begin{array}{l}\text { Pakeista įstatymo taikymo sritis - taiko- } \\
\text { ma tik neprofesionaliems investuotojams } \\
\text { skirtiems KIS, jei jie nesiūlomi viešai; } \\
\text { panaikinta profesionaliojo investuotojo } \\
\text { sąvoka; KISI nebereglamentuoja RDF; } \\
\text { panaikinti straipsniai, kalbantys apie pro- } \\
\text { fesionaliuosius investuotojus ir su tokiems } \\
\text { investuotojams skirtu specialiujų KIS ma- } \\
\text { žesnius veiklos apribojimus. }\end{array}$ & $\begin{array}{l}\text { Nauja istaty- } \\
\text { mo redakcija. } \\
\text { Isigaliojo nuo } \\
2013-07-01\end{array}$ \\
\hline 8 & $\begin{array}{l}2013 \text { m. bir- } \\
\text { želio } 18 \text { d. Nr. } \\
\text { XII-375 }\end{array}$ & $\begin{array}{l}\text { Priimtas Informuotiesiems investuoto- } \\
\text { jams skirtų kolektyvinio investavimo } \\
\text { subjektu įstatymas }{ }^{10} \text {. Teisès aktas skirtas } \\
\text { naujai besisteigiantiems AIF ir anksčiau } \\
\text { veiklą pradejjusiems AIF, jei jie atitinka } \\
\text { istatymo reikalavimus. }\end{array}$ & Isigaliojo nuo \\
\hline 9 & $\begin{array}{l}2014 \text { m. gruo- } \\
\text { džio } 18 \text { d. Nr. } \\
\text { XII-1467 }\end{array}$ & $\begin{array}{l}\text { Priimtas Profesionaliesiems investuoto- } \\
\text { jams skirtų kolektyvinio investavimo su- } \\
\text { bjektų valdymo įmonių įstatymas. }\end{array}$ & $\begin{array}{l}\text { Isigaliojo nuo } \\
2015-01-01\end{array}$ \\
\hline
\end{tabular}

Šaltinis: sudaryta autorių, remiantis Jarašius, G., $2014^{11}$

Vertinant teisès aktų įtaką AIF plètrai Lietuvoje 2008-2014 metais, 6 paveikslèlyje pateikti AIF veiklą apibūdinantys statistiniai dydžiai, kartu laiko grafoje pažymėti atlikti teisès aktų pakeitimai (skaičiai prie rodyklių atitinka 1 lentelëje pateiktų pakeitimų numeraciją). AIF veiklą ir jos dinamiką lemia daugelis aplinkybių ir veiksnių, tačiau ryškūs ir nukrypstantys nuo besiformuojančių tendencijų AIF veiklos rodikliai leistų daryti tam tikras išvadas

${ }^{10}$ Techniniai ịstatymo pakeitimai dèl euro įvedimo šioje lentelèje nenagrinèjami.

${ }^{11}$ Jarašius, G. Alternatyvaus investavimo fondu ịtaka Lietuvos ekonomikai: daktaro disertacija. Vilniaus universitetas. Vilnius, 2014. 265 p. 
apie teisès aktų ịtaką AIF veiklai, jei šiuos pasikeitimus būtų galima susieti su tuo pačiu metu vykusiais reguliavimo pokyčiais. Tokias j̨žvalgas leidžia daryti ir grafinè analizè, todèl detaliai tiriant 6 paveikslèlyje pateiktas tendencijas galima įvertinti, ar ịvykę AIF reguliuojančių teisès aktų pakeitimai galëjo turèti esminès įtakos šių fondų veiklai Lietuvoje.

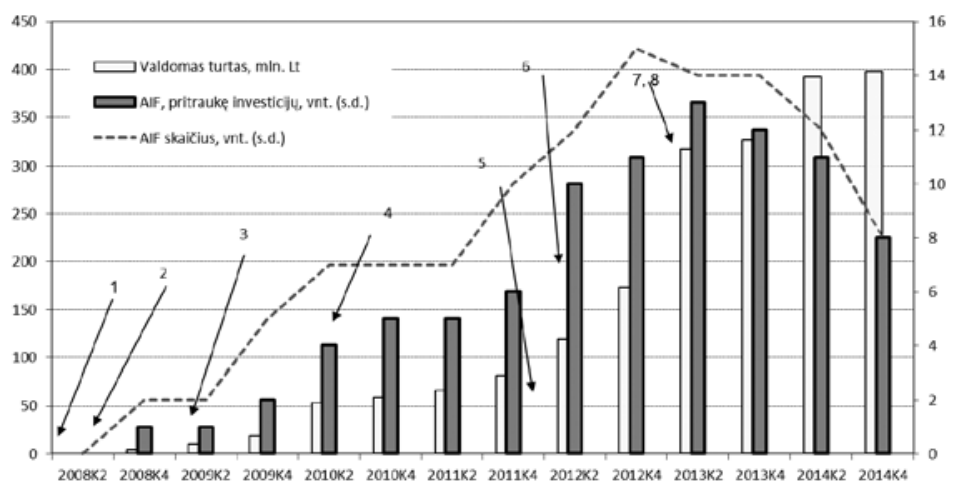

6 pav. AIF plètra ir KISI pokyčių sąsajos 2008-2014 m.

Šaltinis: sudaryta autorių, remiantis Lietuvos..., $2015^{12}$, Lietuvos..., $2007^{13}$

Nuo KISI ịsigaliojimo, kai atsirado galimybè steigti AIF (1 numeris paveikslèlyje), iki $2012 \mathrm{~m}$. pradžios, kai įsigaliojo nauja KISI redakcija (5 numeris paveikslèlyje), buvo atlikti trys tarpiniai teisès akto pakeitimai. AIF veiklos duomenys šiuo laikotarpiu rodo pakankamai spartų augimą, kuris ypač suaktyvėjo nuo $2009 \mathrm{~m}$. vidurio. Tačiau šis augimas buvo nulemtas ne teisinès aplinkos pokyčių, o bendros makroekonominès šalies padèties gerejjimo ir didejjančio investuotojų susidomejjimo šia investicijų kryptimi, besibaigiant šalį apèmusiai finansinei krizei ir gerẻjant investuotojų lūkes-

${ }^{12}$ Lietuvos bankas (2015). Kolektyvinio investavimo subjektų rinkos apžvalgos. Prieiga per internetą: http://www.lb.lt/apzvalgos_prognozes.

${ }^{13}$ Lietuvos Respublikos kolektyvinio investavimo subjektu įstatymo pakeitimo istatymas Nr. X-1303. Valstybès žinios. 2007, Nr. 117-4772. 
čiams. Šị teiginị pagrindžia ir G. Jarašiaus darbe nurodytas faktas, kad per laikotarpi nuo 2008 iki 2012 metų atlikti KISI pakeitimai buvo neesminiai ir daugelis jų AIF reguliavimo nekeitè. Šie pakeitimai buvo susiję su konkretesniu (bet ne veiklą lengvinančiu) NTF reguliavimu, o AIF rinkos augimą iš pradžių lèmė besisteigiantys kitos rūšies, konkrečiai - PKF ir RDF, fondai ${ }^{14}$. Vèlesniais ketvirčiais, ypač nuo $2011 \mathrm{~m}$. pradžios, rinkoje pradejjo dominuoti NTF. Spartų NTF augimą lèmé pirmojo įsteigto, „bandomojo“ NTF sèkmè, vèliau ta pati valdymo ịmonè pradejjo steigti ir kitus NTF, kurie taip pat sèkmingai veikè. Ir NTF sparti plètra neturètų būti siejama su teisès aktų pakeitimais, nes dèl 2, 3 ir 4 numeriu pažymètų KISI pakeitimų NTF veikla nebuvo realiai palengvinta ar supaprastinta.

6 paveikslèlyje 5, 6 ir 7 numeriais pažymėtos naujos KISI redakcijos. KISI redakcija, įsigaliojusi nuo $2012 \mathrm{~m}$. pradžios, esminių pakeitimų AIF neturejo, tačiau 6 ir 7 numeriais pažymètos KISI redakcijos jau yra susijusios ir su nemenkais pokyčiais AIF reguliavimo srityje. Nuo $2011 \mathrm{~m}$. pabaigos (t. y. po KISI pakeitimo, pažymėto 5 numeriu) AIF skaičius, jų valdomas turtas ir veikiančių AIF skaičius pradejjo sparčiai augti. $2012 \mathrm{~m}$. pradžioje AIF skaičiaus ir valdomo turto augimą lèmé du ịsteigti PKF, o vélesniais laikotarpiais valdomo turto augimui didžiausios įtakos turèjo NTF, kurie buvo ịsteigti dar iki 2012 m. II ketv. (t. y. KISI pakeitimo, pažymèto 6 numeriu).

Vis dèlto negalima teigti, kad stebimoms augimo tendencijoms įstatymo nuostatų keitimai galèjo turèti įtakos, ir tai lëmė keletas priežasčių. Nors PKF veiklos reikalavimai ir buvo kiek supaprastinti (20 proc. padidintas leidžiamas naudoti sverto dydis, leista skolinti 50 proc. daugiau), tačiau pagerinimas buvo tik teorinis, nes AIF veiklos duomenys rodo, jog Lietuvoje registruoti AIF finansiniu svertu naudojasi neaktyviai (PKF nèra būdingas aukštas naudojamo sverto lygis), taip pat retai skolina. NTF valdomo turto augimas buvo nulemtas dar prieš KISI pakeitimus pačių fondų valdytojų priimto sprendimo. Iki KISI pakeitimų įsteigti NTF keletą metų formavo

${ }^{14}$ Jarašius, G. Alternatyvaus investavimo fondu ịtaka Lietuvos ekonomikai: daktaro disertacija. Vilniaus universitetas. Vilnius, 2014. 265 p. 
savo portfelius ir pritraukinejo investuotojus, todèl tai, o ne įstatymo pakeitimai, lèmé nuosekliai augantị AIF turtą.

Lygiagrečiai su KISI pradejjus veikti IIKISI ( 8 numeris 6 paveikslèlyje), liko galimybe iki 2013 m. vidurio veikusiems AIF tęsti veiklą pagal galiojusias KISI nuostatas. Iki 2014 m. didžioji dalis veiklą vykdžiusių AIF šia galimybe ir pasinaudojo, todèl IIKISI prièmimo laikotarpiu nèra stebima jokia teisinio reguliavimo pakeitimo ịtaka nei AIF skaičiui, nei jų valdomam turtui. Pradedant 2014 m. jau matomi struktūriniai AIF skaičiaus pokyčiai, kuriuos nulèmė IIKISI. AIF skaičiaus kitimas matomas todèl, kad 6 paveikslèlyje pateikta tik pagal KISI veikiančių AIF informacija, nes pradejję veikti pagal IIKISI arba naujai ikurti AIF, kurie vadovaujasi IIKISt nuostatomis, neskelbia duomenų viešai, taip pat ir priežiūros institucija nepateikia informacijos apie šiuos fondus, todèl nagrinejjamu metu nèra imanoma ivvertinti ir pateikti jų veiklos apimčių ${ }^{15}$. Per $2014 \mathrm{~m}$. iš viso 4 AIF persitvarkè veiklą pagal IIKISI, tai lèmè ir mažejantị 6 paveikslèlyje pateiktų AIF skaičių. Bendras AIF skaičius (įskaičiuojant ir pagal IIKISI veikiančius AIF, šie duomenys matyti 4 paveikslèlyje) keitėsi nedaug, nes dalis fondų tiesiog persitvarkè, keletas fondų nutraukè veiklą, tačiau veiklą pradejjo nauji AIF (pagal IIKISI). Pagal KISI veikiančių AIF skaičius sumažejjo pakankamai smarkiai (nuo 15 fondų $2013 \mathrm{~m}$. I ketv. iki 8 fondų 2014 m. pabaigoje), tačiau priešingai nei galima tikètis, jų valdomas turtas ne mažèjo, o netgi padidèjo. Tai nulèmè NTF veikla, nes šio tipo AIF sudaro didžiausią santykinę AIF veiklos dalį, o iš veikusių NTF tik vienas iš smulkesnių fondų veiklą pertvarkè pagal IIKISI, kiti ir toliau veikia pagal KISI ir didina savo valdomą turtą.

PIKISVIt prièmimas 6 paveikslèlyje pateiktiems duomenims tiesiogiai itakos neturès, nes jis reguliuos fondų valdytojus, kurie valdo daugiau nei $500 \mathrm{mln}$. eurų (100 mln. eurų, kai naudojamas finansinis svertas). Ana-

154 paveikslèlyje yra pateikti vieninteliai prieinami duomenys apie AIF, veikiančius pagal IIKISI, t. y. tokių fondų skaičius. 6 paveikslèlyje AIF skaičius sąmoningai nèra didinamas fondais, veikiančiais pagal IIKISI , kad būtų geriau atspindimos įstatymų pakeitimų nulemtos tendencijos. Bet kuriuo atveju, pagal IIKISI veikiančių AIF valdomo turto apimtys nèra žinomos. 
lizuojant duomenis matyti, kad artimiausiu metu šis įstatymas nèra aktualus reguliavimo požiūriu, nes $2014 \mathrm{~m}$. pabaigoje 3 AIF valdymo i̇monių bendras turtas siekè tik kiek daugiau nei $115 \mathrm{mln}$. eurų. Nors pagal PIKISVIt visos valdymo įmonés privalo kas pusmeti teikti informaciją priežiūros institucijai apie vykdomą veiklą ir turimas pagrindines pozicijas, tiesiogiai įmonių veiklai ịtakos tai neturi, išskyrus tam tikru laipsniu didejjančią administracinę naštą.

Atlikus teisès aktų, reglamentuojančių AIF veiklą, pakeitimų analizę ir susiejus juos su AIF pagrindinių rodiklių pokyčiais Lietuvoje, galima padaryti keletą išvadų. Pirmiausia galima pritarti B. Galinienès ir G. Jarašiaus tyrime pateiktam teiginiui, kad KISI pakeitimai neturejo aiškios įtakos AIF skaičiaus ar valdomo turto apimties augimui per laikotarpi nuo $2008 \mathrm{~m}$. iki $2011 \mathrm{~m}$. pabaigos ${ }^{16}$. Šis teiginys grindžiamas tuo, kad atskiri KISI pakeitimai neapèmė plačių reguliavimo sričių ir daugeliu atvejų ne ribojo, o tik kiek supaprastino AIF taikomą reguliavimą. Vẻlesniais laikotarpiais, net ir įvertinus dažną KISI keitimą, taip pat nematyti tiesioginès teisinio reguliavimo pakeitimo ịtakos AIF veiklai. Paskutinieji pakeitimai, susiję su naujų investuotojų kategorijų ir naujų fondų juridinių formų ịtraukimu, neabejotinai turejo įtakos AIF rinkai Lietuvoje, tai puikiai iliustruoja besikeičianti AIF, veiklą vykdančių pagal IIKISI, skaičiaus struktūra ir dinamika (iš dalies tai atspindi 4 paveikslèlis). Vis dèlto nepakanka duomenų poveikị ịvertinti kiekybiškai, nes priimti pakeitimai sumažino fondų valdytojų atskaitomybę.

\section{AIF atskaitomybès ir priežiūros reikšmè sisteminès rizikos atsiradimui}

Kaip matyti iš analizuotos teisès aktų raidos, atlikti pakeitimai daugeliu atvejų palengvino ar supaprastino sąlygas fondų valdytojams ir patiems fondams, tai neapsunkina ir nestabdo AIF plètros Lietuvoje. Nors AIF

${ }^{16}$ Galinienè, B., Jarašius, G. Regulation and development of alternative investment funds in Lithuania. Вісник Кийвського наиіонального університету імені Тараса Шевченка. Экономіка. 2012, nо. 140, p. 37-40. 
prisideda prie investicinès aplinkos Lietuvoje gerinimo ir suteikia kitų nemenkų privalumų, tačiau galima įžvelgti tam tikrų neigiamų pasekmių viešajam interesui ir ekonomikai apskritai. Iš 7 paveikslèlyje pateiktų pavyzdžių, kokị poveikį AIF gali turèti ekonomikai, matyti, jog šis poveikis gali būti ne tik teigiamas. AIF dèl savo veiklos ypatumų ir galimų investicinių priemonių spektro gali turèti didesnę ịtaką finansų sistemai ir rinkai nei ịprasti investiciniai fondai. Paveikslèlyje pateikti pagrindiniai visų rūšių AIF poveikio ekonomikai būdai, tačiau šiame straipsnyje bus aptariama ir nagrinejama tik aktualiausia sritis - finansinio sverto naudojimas ir su tuo susijusios rizikos.

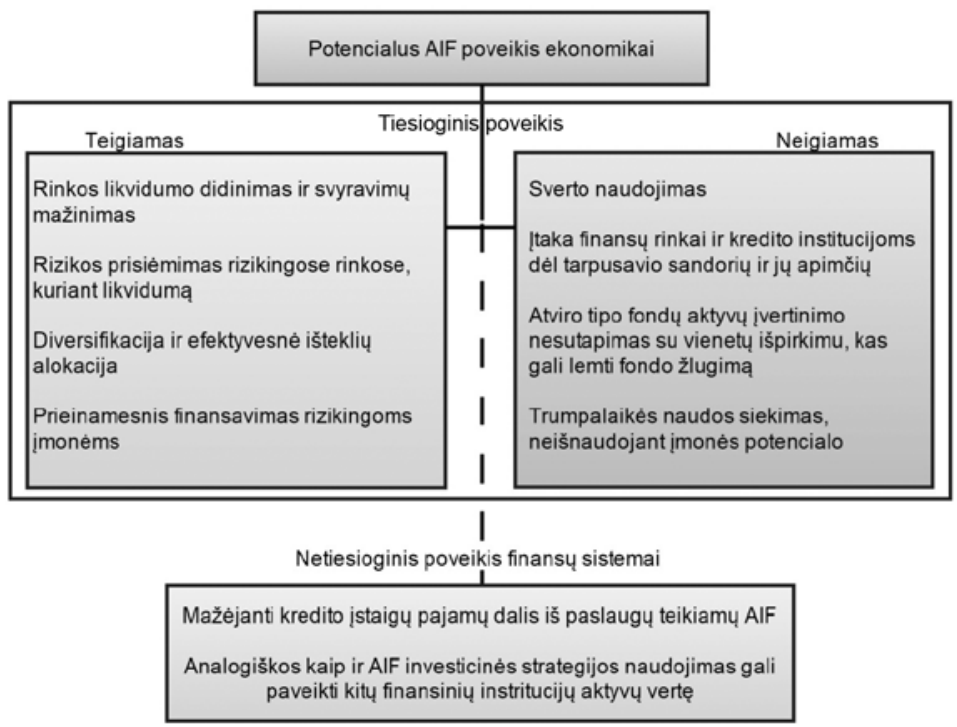

\section{7 pav. AIF poveikio ekonomikai būdai}

Šaltinis: sudaryta autorių, remiantis Jarašius, G., 2014 ${ }^{17}$

${ }^{17}$ Jarašius, G. Alternatyvaus investavimo fondu ịtaka Lietuvos ekonomikai: daktaro disertacija. Vilniaus universitetas. Vilnius, 2014. 265 p. 
Kaip pabrèžia G. Jarašius, viena iš pagrindinių neigiamų rizikų kyla iš RDF ir yra susijusi su pertekliniu sverto naudojimu ${ }^{18}$. Nors kitoms AIF rūšims sverto naudojimas nèra būdingas, tačiau taip pat aktualus ir ne mažiau pavojingas. Todèl reguliuojant AIF turi būti siekiama balanso, nesukuriant perteklinio reguliavimo tų AIF veiklos sričių, kurios nèra esminès sisteminei rizikai susidaryti ir kurias efektyviai reguliuoja pati rinka, ir taip nesumažinant teigiamo AIF poveikio ekonomikai. Kartu daugiau dèmesio turi būti skiriama toms sritims, kuriose kyla sisteminè rizika ir kurios gali labiausiai paveikti finansų sistemą. Viena iš sisteminès rizikos susidarymo sričių yra finansinio sverto naudojimas, su šiuo veiksniu glaudžiai susijęs ir informacijos apie turimas pozicijas atskleidimas priežiūros institucijoms.

Vienas iš esminių AIF rizikos veiksnių, susijusių su efektyviu ir stabiliu ekonomikos sistemos funkcionavimu - leidžiamas naudoti sverto dydis. 2 lentelèje pateikiamas sistematizuotas šio dydžio kitimas skirtingoms AIF rūšims, keičiantis KISI redakcijoms ir priimant naujus teisès aktus.

\section{2 lentelè. Leidžiamo naudoti sverto dydžio kitimas}

\begin{tabular}{|c|c|c|}
\hline \multicolumn{3}{|c|}{ Iki 2012-06-30 } \\
\hline RDF & PKF & NTF \\
\hline Iki 200 \% & Iki 80 \% & Iki 75 \% \\
\hline Nuo 2012-07-01 iki 2013-06-30 \\
\hline RDF & PKF & NTF \\
\hline Nenustatyta & Iki 100\% & Iki 50 \% \\
\hline RDF & PKF 2013-07-01 & NTF \\
\hline Nereglamentuojami & Iki 80 \% & Neleidžiama \\
\hline \multicolumn{3}{|c|}{ Nuo 2013-07-01 (pagal IIKISI) } \\
\hline \multicolumn{3}{|c|}{ Nenustatyta } \\
\hline
\end{tabular}

Šaltinis: sudaryta autorių

18 Ten pat. 
Kaip matyti iš lentelès duomenų, sverto dydžio apribojimai atskiroms fondų rūšims buvo keičiami skirtingai, tačiau aiški bendra tendencija, jog sverto dydis buvo didinamas arba visiškai atsisakoma jo reglamentavimo įstatyme. IIKISI sverto dydis nèra konkrečiai nustatomas, jis turi būti numatytas tik steigiamo fondo dokumentuose. KISI redakcijoje, galiojančioje nuo $2013 \mathrm{~m}$. vidurio, nustatytas tik PKF naudojamo sverto dydis, NTF neleidžiama naudoti sverto, o RDF apskritai nereglamentuojami šiuo i̊statymu. Vis dèlto pagal šią KISI redakciją veikiantys fondai neturètų būti laikomi AIF, todèl apibendrinant galima teigti, jog nagrinėjamu metu AIF sverto dydis nèra įstatymiškai reguliuojamas. Tai kelia tam tikrų rizikų dèl perteklinio sverto naudojimo ir su juo susijusių pasekmių, jei ekonomikoje susiklostytų kritinè situacija. Nors istoriniai duomenys rodo saikingą Lietuvoje veikiančių AIF sverto naudojimą, tačiau tai yra itin svarbi sritis sisteminei rizikai atsirasti, todèl turètų būti reglamentuojama griežčiau.

Kartu su finansinio sverto naudojimo dydžio nustatymu ir reguliavimu, ne mažiau reikšmingas veiksnys, galintis sudaryti prielaidas atsirasti sisteminei rizikai yra fondų atskaitomybè ir prievolè atskleisti informaciją priežiūros institucijoms. Laiku gaunama informacija sudaro prielaidas tinkamai reaguoti ị besiklostančią situaciją rinkoje, todèl 3 lentelèje pateiktos AIF prievolès, susijusios su informacijos atskleidimu.

\section{3 lentelè. AIF prievolès informacijos atskleidimui}

Iki 2013-06-30 (profesionaliesiems investuotojams skirtiems KIS pagal KISț)

Privaloma parengti metinę audituotą ir pusmetinę ataskaitas ir pateikti priežiūros institucijoms ir investuotojams.

NTF privalo pateikti ir papildomą informaciją su metinėmis ataskaitomis apie portfelio objektus (pardavimus, jų veiklą ir pan.)

Nuo 2013-07-01 (pagal IIKISI)

Privaloma metinè audituota ataskaita su esminių funkcijų vykdymo ataskaita, teikiama investuotojams ir priežiūros institucijai.

Kas 6 mèn. priežiūros institucijai teikiama informacija apie ịsipareigojimų vertę, ̨̇siskolinimo dydị, dalyvių skaičių, investicijų portfelio sudètị. 


\begin{tabular}{|c|c|}
\hline \multicolumn{2}{|c|}{ Nuo 2015-01-01 (pagal PIKISVIt) } \\
\hline Visiems AIF & AIF, kai jiems taikomas PIKISVItt \\
\hline $\begin{array}{l}\text { Privaloma kas } 6 \text { mèn. pa- } \\
\text { teikti informaciją priežiū- } \\
\text { ros institucijai apie platina- } \\
\text { mus investicinius vienetus } \\
\text { ar akcijas ir apie pagrindines } \\
\text { pozicijas bei rizikos koncen- } \\
\text { tracijas. }\end{array}$ & $\begin{array}{l}\text { Kas } 3 \text { men. atnaujinti informaciją, susijusią su } \\
\text { likvidumu ir rizikos pobūdžiu bei rizikos valdy- } \\
\text { mo sistemomis, ir padaryti prieinamą priežiū- } \\
\text { ros institucijai ir investuotojams. } \\
\text { Kas } 1 \text { mèn. investuotojams turi būti atnaujina- } \\
\text { ma informacija apie didžiausio galimo naudoti } \\
\text { finansinio sverto lygio pakeitimus, taip pat ben- } \\
\text { drą sverto dydì. } \\
\text { Priežiūros institucija renka duomenis apie finan- } \\
\text { sinio sverto naudojimą, ir gali nustatyti maksi- } \\
\text { malaus finansinio sverto naudojimo ribas ar ki- } \\
\text { tus apribojimus. } \\
\text { Privaloma metine audituota ataskaita su kita in- } \\
\text { formacija apie fondo veiklą, kuri prieinama tik } \\
\text { investuotojams ir priežiūros institucijai. } \\
\text { Valdymo įmonès turi pateikti priežiūros institu- } \\
\text { cijai ịrodymus, kad nustatytos kiekvieno jų val- } \\
\text { domo kolektyvinio investavimo subjekto finan- } \\
\text { sinio sverto ribos yra pagrịstos ir kad jos visada } \\
\text { laikosi tų ribų. }\end{array}$ \\
\hline
\end{tabular}

Šaltinis: sudaryta autorių

Kaip matyti iš lentelès duomenų, AIF priežiūros institucijoms teikiama informacija ir jos apimtis mažai keitèsi keičiant teisès aktus, ir tik prièmus PIKISVIt pradètos griežčiau reguliuoti sritys, iš kurių gali rastis sisteminė rizika - t. y. AIF valdytojai privalo gana dažnai (kas 1 ar kas 3 mèn.) teikti informaciją, susijusią su sverto naudojimu, turimomis pozicijomis ir likvidumu. Autorių nuomone, tokio pobūdžio ir apimties duomenų teikimas, atsižvelgiant ir ị PIKISVIt numatytą tokių duomenų teikimo periodiškumą, buvo siektinas dalykas ir tai sudaro geras sąlygas priežiūros institucijoms efektyviai reguliuoti AIF bei užkirsti galimybę atsirasti sisteminei rizikai. Kartu yra išlaikomas reguliavimo balansas, nes nèra prašoma per daug ar perteklinės informacijos 
ir AIF nèra per daug apkraunami su jų pagrindine veikla nesusijusiomis užduotimis. Vis dèlto, kaip jau buvo minèta, PIKISVIt nuostatos yra labiau teorinès, nes šiuo metu nèra tokių fondų valdytojų, kuriems šis ịstatymas galiotų visa apimtimi. Nagrinejjamu metu PIKISVIt svarbus tuo, kad pagal ji net ir neatitinkantys minimalaus slenksčio AIF valdytojai turi reguliariai (kas 6 mèn.) teikti tam tikrą informaciją (investavimo strategiją, naudojamas investicines priemones, rizikos koncentraciją) priežiūros institucijai.

Šiuo metu veikiantys AIF vadovaujasi IIKISIt, kurị laiką ir KISI, pagal kuriuos AIF taikomi gerokai mažesni atskaitomybės ir viešumo reikalavimai. Nors priežiūros institucijai įstatymais numatyta teisẻ bet kuriuo metu reikalauti pateikti papildomą informaciją, tačiau nuolat ir reguliariai yra teikiamos tik metinès ir pusmetinès ataskaitos ir nèra išskirtas informacijos apie naudojamą finansinị svertą pateikimas. Dalis tokios informacijos atsispindi finansinejje atskaitomybèje, tačiau dèl jos teikimo periodiškumo ir ịvertinant laiką, per kurị atskaitomybẻ turi būti parengta, tokia informacija tampa mažai reikšminga ir nebeaktuali.

Galima suprasti ekonominę logiką, pagal kurią tik dideliems fondų valdytojams (nuo $100 \mathrm{mln}$. eurų, kai naudojamas finansinis svertas) yra privaloma dažnai teikti informaciją, susijusią su rizikos valdymu, tačiau, autorių nuomone, panašios informacijos priežiūros institucija galètų reikalauti ir iš AIF, veikiančių pagal IIKISĮ. Tokị poreikį galima pagrịsti tuo, kad PIKISVIt priimtas igyvendinant EP ir Tarybos direktyvas, kurios taikomos bendrai ES, todèl ir valdomo turto apimtys yra pritaikytos visos ES mastu. Lietuvos rinka yra gerokai mažesnè ir fondai vargiai pasiekia tokias valdomo turto apimtis, tačiau net ir pagal dabartinę situaciją AIF valdomas turtas jau sudaro nemažą dalị visos KIS turto dalies. Atsižvelgiant ir ị vis didejantị finansinio sverto naudojimą, tampa aktualu prižiūrèti sisteminės rizikos šaltinius ir tuo atveju, kai AIF yra mažesnių apimčių (kai reguliuojami IIKISI). 
Taip pat verta paminėti, jog keičiantis teisès aktams, suprastèjo ir informacijos prieinamumas visuomenei. Anksčiau kas ketvirtị Lietuvos banko skelbtos KIS apžvalgos, kuriose buvo apibendrintai aptariami ir AIF, tapo pusmetinès, o prièmus IIKISI, informacija apie AIF, veikiančius pagal šị ịstatymą, iš viso nèra skelbiama (nors Lietuvos bankas planuoja skelbti apibendrintą metinę informaciją apie pagal IIKISI veikiančius fondus). Kadangi AIF neprivalo teikti duomenų viešai ir tai savanoriškai daro ne visi fondai, tapo sudètinga gauti informacijos apie AIF veiklą, todèl, autorių nuomone, turètų būti įteisintos nuostatos pateikti duomenis, reikalingus ịvertinti galimybę atsirasti sisteminei rizikai. Taip pat turètų būti siekiama, kad ir priežiūros institucijos skelbtų tam tikrą apibendrintą informaciją visuomenei, kuria galima būti naudotis ir moksliniais tikslais.

\section{Išvados}

Atlikta teisès aktų, reguliuojančių AIF, pakeitimų ir naujų teisès aktų atsiradimo analizè atskleide், kad nèra matoma aiški teisès aktų pakeitimo ịtaka AIF, registruotų Lietuvoje, veiklai. Net ir pakankamai dažnas teisės aktų kaitaliojimas bei naujų įstatymų ir jų redakcijų prièmimas neapsunkino AIF veiklos, nes daugeliu atvejų pakeitimai būdavo nesusiję su AIF arba palengvindavo jų veiklos sąlygas. Tais atvejais, kai įstatymų pakeitimais būdavo ịteisinami AIF veiklos apribojimai, tai taip pat neturèdavo ịtakos AIF veiklai, nes būdavo apribojamos tos sritys (pvz., sverto naudojimas), kurios ir iki apribojimo nebuvo pasiekusios nustatyto dydžio ir naudojamos ne itin aktyviai.

Nors priimtas teisinis reguliavimas supaprastino AIF steigimą ir veiklą, ir tai ilgalaikejje perspektyvoje turètų pagerinti investicinę Lietuvos aplinką, suteikti vietos investuotojams didesnes pasirinkimo galimybes bei prisidèti prie efektyvios finansų rinkos kūrimo, kartu tam tikru laipsniu sumažejo ir informacijos prieinamumas 
bei AIF viešumas. Nustatant reikalavimus AIF atskaitomybei ir informacijos atskleidimui, turi būti siekiama balanso ir ịvertinama gaunamos informacijos nauda, atsižvelgiant $\mathfrak{i}$ fondams sukuriamą papildomą administracinę naštą. Todèl turi būti siekiama papildomai reguliuoti tik tas sritis, kurios yra reikšmingos sisteminés rizikos atsiradimui. Viena iš pagrindinių tokių sričių yra sverto naudojimas ir informacijos, susijusios su finansiniu svertu, atskleidimas priežiūros institucijoms. Nagrinèjant Lietuvoje egzistuojančias įstatymų nustatytas prievoles šiuo klausimu, matyti, kad sverto naudojimas nèra tinkamai reguliuojamas ir renkama gana nedaug informacijos, susijusios su sverto naudojimu. Todèl turètų būti siekiama, kad informacijos apie finansinio sverto naudojimą atskleidimas taptų panašus ị numatytąj AIF valdytojams, kai jie reguliuojami pagal PIKISVI̦t, t. y. turètų būti siekiama rinkti reikšmingą informaciją apie svertą ne rečiau nei kas 3 mèn. ir iš AIF, veikiančių pagal IIKISI arba KISI (kol pagal ši įstatymą dar veikia anksčiau issteigti AIF). Tai ypač aktualu ir dèl mažo Lietuvos rinko dydžio bei santykinai didelès AIF valdomo turto dalies Lietuvos investicinių fondų rinkoje.

\section{Literatūra ir šaltiniai}

Estonian financial market overwievs (2015). Estijos finansinès priežiūros institucija. Prieiga per internetą: http://www.fi.ee/index. php?id=12737.

Galinienè, B., Jarašius, G. Regulation and development of alternative investment funds in Lithuania. Вісник Кийвського національного університету імені Тараса Шевченка. Экономіка. 2012, no. 140, p. 37-40.

Jarašius, G. Alternatyvaus investavimo fondu ịtaka Lietuvos ekonomikai: daktaro disertacija. Vilniaus universitetas. Vilnius, 2014. $265 \mathrm{p}$. 
Lietuvos bankas (2015). Kolektyvinio investavimo subjektų rinkos apžvalgos. Prieiga per internetą: http://www.lb.lt/apzvalgos_ prognozes.

Lietuvos Respublikos informuotiesiems investuotojams skirtų kolektyvinio investavimo subjektų istatymas Nr. XII-376. Valstybès žinios. 2013, Nr. 68-3410.

Lietuvos Respublikos kolektyvinio investavimo subjektų įstatymas Nr. IX-1709. Valstybès žinios. 2003, Nr. 74-3424.

Lietuvos Respublikos kolektyvinio investavimo subjektų įstatymo pakeitimo istatymas Nr. X-1303. Valstybès žinios. 2007, Nr. 117-4772.

Metinès ataskaitos ir finansinių priemonių rinkos apžvalgos. (2015). Lietuvos Respublikos vertybinių popierių komisija. Prieiga per internetą: http://www.lb.lt/vertybiniu_popieriu_komisijos_ apzvalgos.

Numatomi pasikeitimai fondų veiklos reguliavime Lietuvoje ir Europos Sąjungoje (2012). Lietuvos Respublikos finansų ministerija. Prieiga per internetą: http://www.finmin.lt/finmin.lt/failai/Finansu_rinkos/fm_pristatymas_fondai_LT_EU.pdf.

Schulaka, C. Special report: 2011. Alternative investments. Journal of financial planing. 3 p. Prieiga per internetą: http:// www.fpanet.org/docs/assets/4A726F42-1D09-67A1-7AE0CA9E420DAD2F/SS_Schulaka.pdf. 


\section{DEVELOPMENT OF THE ATLERNATIVE INVESTMENTS FUNDS REGULATION IN LITHUANIA AND POSSIBILITIES FOR THE IMPROVEMENTS IN THE REGULATION}

\section{Birutė GalinienĖ, Gytis Jarašius}

\section{Summary}

Keywords: alternative investments funds; collective investments undertakings; leverage; regulation of the alternative investments funds; professional investor; informed investor.

Alternative investments funds (AIF) became legal in Lithuania since early 2008 and till now they have managed to establish itself in the Lithuanian investment funds market. Therefore, the legal regulation and supervision of such funds becomes even more important. Moreover, AIF funds are potentially more dangerous for the financi- al system than the conventional investment funds. As there were quite a lot changes in the legal acts, analysis of these amendments, regarding AIF regulation and development, were conducted. It was revealed that in some areas, where systematic risk may occur, the regulation of AIF could be more rigorous and supervision could be more intense.

Iteikta 2015 m. gegužès $25 d$. 